\title{
Nomadic education for national integration in Nigeria
}

\author{
Dominic E. Wonah, Anthony G. Bullem
}

\begin{abstract}
The need for the education of the nomads cannot be over-emphasized. Nigeria's population is characterized with many occupations and methods of farming. A feature of the nomads is movement from place to place in a quest for pasture, fertile soil, fishing ponds or rivers and hunting grounds. Importantly, they roam about, and that is why they are called nomads. This group of farmers needs education. Since education has been described as an "instrument for national development and change" by Federal Policy on Education NPE (2010), it is necessary for the migrating farmers to be given an education. This article is therefore investigating how the migrating farmers will benefit from the education intended for them. It is therefore a position paper as information garnered for this paper is extracting from articles, newspapers and journals. The aim of this paper is therefore to examine the strategies adopted in view of repositioning lapses encountered earlier between nomads and staple farmers who are in perpetual disagreement.
\end{abstract}

Keyword: nomads, education, crop farmers, conflict resolution.

\section{Abstrakt}

Potřeba vzdělávání nomádů nemůže být dostatečně zdůrazněna. Populace Nigérie je charakterizována mnoha profesemi a způsoby hospodářství. Charakteristikou nomádů je přesun z místa na místo pro nalezení lepší pastviny, úrodné pưdy, rybníku nebo řeky a loveckých pozemků. Důležité je, že se potulují kolem, a proto se jim říká nomádi. Tato 
skupina zemědělců potřebuje vzdělání. Vzhledem k tomu, že vzdělávání bylo popsáno jako «Nástroj pro národní rozvoj a změnu» federální politiky pro vzdělávání NPE (2010), je nezbytné, aby zemědělci, kteří migrují, byli vzdělání. Tento článek proto zkoumá, jakým způsobem budou zemědělci, kteří migrují, využívat vzdělání, které je jim určeno. Jedná se tedy o práci, kdy informace, které jsou v článku obsaženy, jsou výpisy z článků, novin a deníků. Cílem tohoto článku je proto přezkoumat strategie přijaté s ohledem na přepolohování minulých období mezi nomády a ostatními zemědělci, kteří jsou v neustálém sporu.

Klíčová slova: nomádi, školství, zemědělci, řešení konfliktů.

DOI: 10.5507/epd.2019.032

\section{Introduction}

Nigeria is a country which is multi-characteristic in nature. The major tribes are the Yoruba, Igbo and Hausa. They have been described as "WAZOBIA" meaning "come" in the most well-known three languages of Yoruba, Hausa and Igbo. However, apart from the three major tribes, there are other significant tribes. According to Eheazu (2014) the people of Nigeria spread from the southeast, southwest and far south to the northern and the northwest and north central. The north comprises the Fulani, Kanuri, Idoma, Margi, Kamberi, Karekare, Gwari, Gobir, Igala, Tiv, Nupe, Ebira and others in the south of Nigeria. They include the ljaw, Izon, Etsakor, Urhobo, Itse, Kiri, Ogoni, Ikwere, Ibibio, Efik and Ekoi. There are, however, other smaller ones particularly in the Cross River State that are not mentioned in this piece.

Abdulrahman (2015) asserts that the most important attitudes of these different tribes is that they have distinct occupations, cultures, identity and religions. The geographical and climatic configuration of the country is reflected in the cultural, economic and social lifestyle of the people. The geographical design of the country has inwardly speculated the occupation of the dwellers.

The National Policy on Education (2010) describes Nigeria's coexistence as unity in diversity. Unity in diversity is in the sense that these many tribes have their different cultures and practice them to their best advantage even in trade and agriculture. That is why the north has taken to herding, because their climate suits keeping of animals. This is because the scant rainfall limits possible animal disease. However, in the same vein the Fulani adopted a new approach to the style of their animal rearing. They move from one destination to another even into a different cultural sphere; the citizens exist as a united whole protecting their territorial integrity with serenity. No wonder the call for separating the south east from Nigeria to be renamed as Biafia by the likes of Nnadi 
Kalu is meeting resistance from the Federal Government with an amount of threat. Duru (2018) explains that because of insufficient animal pasture the north, nomads move from place to place. Nomads also exist in the fishing arena, crop farming and hunting. Tarabans in the upper Benue are predominantly fisherman. During the dry period, they move downwards where stagnant water exists. Down south, those migrant fishermen move from one part of the river Niger to the other, seeking shallow water ranges. It is therefore noted that cultural affiliation, religion, trade, social life in marriage, and dance is very peculiar to the nature of settlement during their movement.

\section{The Concept of Nomadism}

Nomadism connotes movement from place to place. This is usually done seasonally and normally for the search of grazing ground or for hunting and fishing. Eheazu (2014) describes nomadism as people without permanent homes and wanderers, itinerants, with no fixed residence and who roam about in search of grazing land. The Federal Ministry of Education (2005) does not differ except in nomenclature. It says, "Nomadism is movement from one place to another along a traditional circuit in search of pasturage or food". The fishing and hunting teams are also nomads because they move about seasonally, hunting for their prey as the animals of the hunt moves for their own food or protection. Ayieke (2014) explains the concept as of tribes who move from place to place in search of pasture or food. He is a wanderer and in clearer terms, a nomad is a wanderer, migrant, rover, rambler, itinerant, drifter and vagabond. All these are said about the nomad because he does not have any intention to return back to his starting point. The population of nomads ranges between 7 million and 7.8 million people.

\subsection{The Concepts of Nomadic Education}

Abdulrahman (2012) intimates that Islamic education flourished in the north because of the north's association with Arabic traders. Because Mali, the Niger Republic, North African States are mostly Muslims they embrace Islamic education. It is therefore not surprising that education was the instrument of religion. This being the case, the Europeans who penetrated the southern part of the country brought English which became the official language of Nigeria and indeed made scholarly activity a truism in the south using English as the instrument. The north became comfortable with what first came to them. Abdulraham (2012) said that Islamic education was at the detriment of formal education. He continued by saying that Islamic education is not the language of business and governance in Nigeria, so the practitioners were likely to be disadvantaged. $\mathrm{He}$ is of the view that because of the lack of formal education, the north took to cattle rearing as the most important occupation. Even though the north is more populous 
and embrace Islamic education, since the Europeans colonized the country, English became the official language.

\section{Methods of Imparting Education to the Nomads}

Audu (2016) advocates that for nomadic education to work well, ranches would be established to settle the nomads. The movements of families from one place to another, he said was unhealthy. Human beings are expected to have residence where they were sure to be buried after death. A permanent home (the ranch) would serve this purpose. This will establish national integration since the ranches were to be established in almost all the states.

Audu (2016) further suggests that irrigation would be constructed for regular supplies of water for the growth of high quality improved tropical grass and legume species to serve as food for the cattle and sheep.

Model schools were to be built for the children of the nomads. Indeed, in this school adult learners were to be admitted for the privilege of having western education. Qualified teachers and regular supervision were to be affected for high quality education.

Ahmed (2016) gives kudos to the government for the plan but warns that such investment is capital intensive. The building of irrigation and the hiring or employment of seasoned teachers can be challenging. He is aware of government projects started with good intentions that have been abandoned by another generation of politicians. But this would have served as a panacea for the constant clashes between the crop farmers and most herdsmen. Most crop farmers have permanent abodes and operate within their boundaries. Indeed, the farmlands which they operated on are either inherited from their ancestral links or bought by themselves. Abionak (2018) highlights the wanton killings of crop farmers in Benue, Cross River, Tarab,a and Enugu also states it is important to educate the cattle rearers socially, morally, psychologically so that they can practice what they have learnt in order to curb the massive conflict generated between the nomadic and crop farmers. Cattle rearers have sophisticated weapons and are able to do serious harm to the natives of the locality. When their cattle graze on the natives' crops, there are bound to be complaints. Often these complaints are concerned with the slaughtering of the owners of the crops and permanent owners of the land that the cattle graze on.

It is however surprising that Bayeri (2016) a spokesperson for Miyelti Allah Cattle Breeders Association under the umbrella body of the Fulani herd men was vehement against the establishment of ranches. In his own words "we shall prefer to explore our traditional grazing routes/reserves". This offer from the Federal Government should have given the cattle breeders and herdsmen opportunity to embrace the western education which is formal and business oriented. 


\subsection{Managing Conflicts between Nomadic and Crops Farmers in Nigeria}

The introduction of education for nomads as a way towards sustenance is a development that can bring anticipated peace to the nation. If education is embraced by the Fulani nomads, their approach would change. Since education is the pivot on which all developmental strata are baked, education is bound to create a permanent change on the lives of the nomads. By sensitization, nomads are bound to accept settlement in the ranch earlier rejected by them; Bayeri (2016).

\section{Conclusion}

The developing countries have many hurdles to jump. They face the problems of poor electricity generation, bad roads, poor sources of water, insufficient healthcare, and poor educational facilities. These attributes of the conditions that prevail in the developing countries limit development.

In the Middle East, which traditionally included herders - cattle rearing, sheep, donkeys- they have adopted the Ranch system of rearing their animals. The Ranch System as advocated earlier by Audu (2016) brings civilization to the rearing of cattle, sheep etc. In this system, schools will be built, and properly trained teachers will be sent to the schools. Irrigation systems will be provided to serve as a source of water. Improved tropical grass and legume species will be planted to serve as food for the cattle and sheep. The itinerant fishermen and pastoralists (herdsmen) number about 9.0 million people. This population is a significantly integral part of the Nigerian nation and must be adequately cared for by the Nigerian government.

By this arrangement, they can establish ancestral links. In other words, they would have a permanent burial ground which in the African culture establishes the link of where one comes from. It is further stated by Kaye (2015) that Ghana has adopted the Ranch system. This System is bringing development as the herdsmen are no longer in constant clash with the native crops farmers. The government of Ghana has expelled all invading herdsmen from neighbouring West African countries from their territory and Nigeria can use their constitutional rights to do same.

\section{Recommendations}

It is clear that what the herdsmen need before they will accept the ranch system is assurance of the good things promised them. Governments should therefore make sure that they can put in place the promises made. Ghana imposed sanctions on herdsmen who 
were vehement against the establishments of ranches. Nigeria has a constitutional right to impose well-informed legislation on its citizens. This is more possible when the lower and upper legislators have passed a bill to the effect of establishing Ranches. Nigeria with an estimated population of 190 million cannot stay aloof and allow a negligible population of the herdsmen of about ten million people to destabilize the country, by grazing on unlawful farmlands. The government should put all hands-on deck to implement the establishment of ranches. It will bring the long looked for peace between the crop farmers and their counterparts, the herdsmen.

\section{References}

Abdulrahman. Y. M. (2015). Trends and Innovations in Education of Nigeria Nomadic Population. Retrieved 6h August 2017, from uniport.edu.ng nec.

Abionak (2003). The use of media in adult education. A paper presented at a one-day workshop organized for local adult literacy officers of agency for adult and non-formal education. Oyo State, Nigeria.

Ahmed. E. (2000). The design of personal mobile technologies for lifelong learning. Computers \& Education, 34(3), 177-193.

Audu, O.(2016). Ranching for the Fulani herdsmen. The Nations Newspaper Thursday 12th April pg 42.

Ayieke, G. (2014). Movements and demography of Fulani nomads. Kaduna: Baraka Press.

Bayeri, D 2016) Fulani herdsmen grievances The Nations Nevispaper Wednesday 16th June, Pg 52.

Duru, I. (2018). The Nation Newspaper Thusday 20th Oct. pg 32.

Wikipedia (2018). African Literacy Level. Retrieved on the 16 January 2019 http:www.isma.org.uk Eheazu, B. A. (2014). Nomadic Education Centre. University of Port Harcourt. Retrieved IOth August 2017, from www.uniport.edung/nec.

Federal Ministry of Education (2005). Education sector analysis (ESA). Abuja: FME Publication.

Federal Republic of Nigeria (2006). National Population Commission News. Abuja: GEBOS

Iro, I. (2006). Nomadic education for nomadic Fulani. Retrieved August 12th, 2017 from: http:// www. am lani7.htm.

Kaye, H. R. (2015). Distance education in Lifelong Education for Adults: An International Handbook. pp.50 Ford Paragon press.

Federal Republic of Nigeria (2010). National Policy on Education. Abuja: FME Publication.

Federal Republic of Nigeria (1993). New Primary Education Commission. Abuja.

\section{Contact:}

Dominic E. Wonah

Anthony G. Bullem

Continuing Education/Developmental Studies

Faculty of Education, University of Calabar

Etagbor, PMB 1115 Calabar 2018

Nigeria

E-mail:dominicwonah@unical.edu.ng 
Dr. Dominic E. Wonah is senior Lecturer in the Department of Continued Education and development studies, university of Calabar, Nigeria. He joined the University of calabar after his Doctoral studies in the same department. He has contributed to growth of his department and the University through research, teaching and community services as well as graduating students at undergraduate and post graduate level. He has many researched articles in both International and local Journals and books to spice his professional growth and enrich literature in his discipline. The Author has equally attended many conferences in Africa and other parts of the world. His research interest is in development studies and national integration.

Associate Prof. Anthony G. Bullem is the current Head of the Department of Continued Education and development studies, University of Calabar. He is an Associate Professor of continued Education, his publications span through many learned international and local Journals, with many books, technical reports and monographs to his credit. He has chaired many conferences and facilitated many workshops that improve quality of lives of rural dwellers. His research interest focused on community development and gender equality. 